\title{
Huaiyuan Epeirogeny - shaping Ordovician stratigraphy and sedimentation on the North China Platform
}

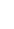

Yong Yi Zhen ${ }^{\mathrm{a} *}$, Yuandong Zhang ${ }^{\mathrm{b}}$, Zhihao Wang ${ }^{\mathrm{b}}$, Ian G. Percival ${ }^{\mathrm{a}}$

${ }^{\mathrm{a}}$ Geological Survey of New South Wales, W.B. Clarke Geoscience Centre, 947-953

Londonderry Road, Londonderry NSW 2753, Australia

${ }^{\mathrm{b}}$ LESP, Nanjing Institute of Geology and Palaeontology, Chinese Academy of Sciences, Nanjing 210008, China

*corresponding author: Tel.0061-2-47770318,E-mail: yong-yi.zhen@trade.nsw.gov.au

\section{ABSTRACT}

Ordovician conodont studies have revealed a depositional hiatus extending from the late Floian to early Darriwilian on the North China Platform. Recognition of this widespread gap entails revision of the original concept of the Huaiyuan Epeirogeny, with definition of two distinct regional tectonic events: Event 1, which initiated this hiatus, and a subsequent Event 2 that was responsible for terminating Early Palaeozoic sedimentation in the region from the late Katian. The timing of these two events partly coincides with widely recognized eustatic sea-level falls, and separates Ordovician sedimentation into two episodes that can be broadly correlated with eustatic sea-level rises. In combination with these sea-level changes, the Huaiyuan Epeirogeny played a decisive role in shaping and controlling Ordovician sedimentation and sequence stratigraphic architecture on the North China Platform. Lower Ordovician carbonates were deposited during an apparent regression (decreasing accommodation space), resulting from rapid sediment accumulation exceeding the overall rate of basement subsidence and eustatic sea-level rise. Sedimentation ceased in the middle 
to late Floian when basement uplift commenced in the south and extended northward to affect the entire platform. The diachronous top surface of the Lower Ordovician succession reflects extensive erosion that is most pronounced in the south and southwest parts of the platform where the disconformity surface cut down into Tremadocian (or even upper Cambrian strata). Deposition of the younger sequence (Darriwilian and Katian) was the result of the interplay between rejuvenated basement subsidence and the late Middle

Key words: Huaiyuan Epeirogeny, Ordovician, eustasy, North China

\section{Introduction}

"Huaiyuan Movement" was a term introduced into the literature by Li Siguang (1939) to describe tectonic uplift of the North China block that resulted in a major interruption of sedimentation between the Lower and Middle Ordovician in the region. Based on faunal evidence and the diachronous nature of the uppermost Cambrian and the Lower Ordovician stratigraphic units deposited to the north of Huaiyangia (a palaeo-land believed to have existed along the south margin of the North China Platform), Zhang and Zhen (1991, p. 237, fig. 13) interpreted this tectonism as a continuous epeirogenic movement extending from the late Cambrian to Middle Ordovician. Song (2001) recognized four stages of the event, including (1) dolomitization, (2) uplift, (3) formation of breccia and erosional surfaces, and (4) formation of slip folds. Since then, a substantial amount of new palaeontological and sedimentological data from the region has become available, particularly conodont studies in 
recent years (Chen et al., 2013; Wang et al., 2013a, b, c; Wang, 2014a, b; Zhen et al., 2015;

Myrow et al., 2015). These data support our synthesis of the timing and intensity of this regional event and recognition of the temporal and spatial extent of the hiatus in sedimentation during the Early and Middle Ordovician on the North China Platform. The newly available data also enable re-evaluation of the nature and possible mechanism of this tectonic event, which is believed to be the major force involved in controlling sedimentation on the North China Platform during the Ordovician and beyond (Silurian to Mississippian).

We have expanded Li's original concept of the Huaiyuan Movement (here termed Huaiyuan Epeirogeny) by recognizing two major regional uplift events affecting the North China Platform. Each of these events produced a major disconformity or low angle unconformity within the Ordovician succession, one separating the Lower and Middle Ordovician (Event 1), and the second (Event 2) separating uppermost Middle to Upper Ordovician rocks from overlying upper Carboniferous strata.

\section{Geological setting}

Present-day China is an amalgamation of a number of palaeo-plates and terranes that were largely scattered off the northeast margin of the Australian Craton during the Ordovician. The Sino-Korean Craton (SKC, also referred to as North China Craton - NCC; Fig. 1) is bounded to the north by the Central Asian Orogenic Belt and to the south by the Qinling-Dabie-Sulu Orogenic Belt (Li and Powell 2001; Kusky et al., 2007; Xiao et al., 2009; Zhai and Santosh, 2013). The SKC is one of the major Archean cratons in the world, with the oldest basement rocks dated at approximately $3800 \mathrm{Ma}$. The craton comprises most of North China and parts of the Korean Peninsula (Fig. 1). It experienced a long and complicated geological history, stabilizing during the Palaeoproterozoic and subsequently 
received a thick succession of Neoproterozoic to Palaeozoic sedimentary deposits (Zheng et al., 2013; Zhao and Zhai, 2013).

During the Ordovician the SKC was largely confined to the tropical zone near the equator, and is interpreted as a peri-Gondwanan terrane located along the northeast Gondwana margin and fringed by subduction-accretion complexes and island arcs (Zhang et al., 1984; Metcalfe, 1996, 1998, 2006; de Jong et al., 2006). However, Cho et al. (2014) presented an alternative view suggesting that the SKC remained part of eastern Gondwana until the end of the Ordovician, and formed an elongated block separated from the northwestern part of the Australian Craton by a vast epicontinental sea. The region covered by this sea, which is now referred to as the North China Platform, was the site of shallow water carbonate-dominated deposition, with Ordovician successions attaining 500-1000 m in thickness. Along its western to southwestern margin even thicker accumulations (up to 2600 m) of mixed carbonates and siliciclastics were deposited in slope to marginal platform environments (Yang et al., 2005; Cao et al., 2011; Feng et al., 2014).

Ordovician rocks in the Chinese part of the craton can be subdivided into three major depositional domains, i.e. western region, northern region and southern region (Fig. 1). The Alashan (also called Alxa) Terrane has been treated as a doubtful part of the SKC in most Ordovician tectonic reconstructions, as its palaeogeographic position during the Early Palaeozoic is still hotly debated (Zhang et al., 2014). Based on evidence from Carboniferous and Permian palaeomagnetic results, Yuan and Yang (2014) indicated that it did not amalgamate with the SKC until late Permian time, but Wu and Min (2015) argued that it merged with the SKC in the Dapingian (Middle Ordovician).

In striking contrast to the South China block that received a relatively complete marine succession during the Ordovician, sedimentation on the SKC was incomplete and significantly disrupted by two major episodes of the Huaiyuan Epeirogeny coupled with 
major eustatic sea-level changes (Fig. 2). More specifically, after deposition of a thick shallow marine succession of carbonate-dominated sediments during Neoproterozoic and Cambrian time, the vast area of the interior North China platform was covered by a shallow epicontinental sea at the beginning of the Ordovician (Fig. 1) with deep-water marginal facies only preserved along its southwestern (An and Zheng, 1990) and northern (Chen, 1986; Zhang et al., 1991) margins. Due to the very shallow water depths, Ordovician sedimentation on this platform was highly sensitive to tectonic uplift and eustatic sea level changes. The first episode (Event 1) of the Huaiyuan Epeirogeny is characterized by the unconformity between the widely distributed Sanshanzi Dolostone (and its time equivalents) of late Cambrian to Early Ordovician age, and the late Middle Ordovician (Darriwilian) succession comprising calcareous shale and thin-bedded limestone (Jiawang Formation) and dolomitic limestones (Beianzhuang Formation). The second episode (Event 2) separates uppermost Middle Ordovician to Upper Ordovician carbonates from the overlying upper Carboniferous succession. Both unconformities are characterized by an uneven surface, particularly the younger unconformity with well-developed karstification and a widely distributed "palaeosol" (e.g. the G layer bauxites) at the base of the Pennsylvanian succession directly overlying eroded Upper Ordovicianstrata (Fig. 2).

\section{Palaeontological evidence}

Event 1 of the Huaiyuan Epeirogeny in the southern region of the platform was initially recognized mainly on palaeontological evidence. Studies of trilobite faunas from the Sansanzi Formation demonstrated diachronous basal and upper boundaries of this distinctive lithological unit. Its base varies from Gushangian (Cambrian Series 3) near the southern margin (e.g. northern Anhui and central Henan) to middle Floian near the northern margin of the platform in eastern Liaoning (An et al., 1983, p. 34; Zhang and Zhen, 1991, fig. 7; Song, 
2001; Fig. 2). Zhang and Zhen (1991, figs 13, 20) suggested that Event 1 was initiated from the palaeo-land or islands fringing the currently preserved southern margin of the SKC, progressively younging northeastward along with a regional regression. Early studies of Ordovician conodonts from North China (An et al., 1983, text-fig. 6; An and Zheng, 1990, table 3), also recognized the wide distribution of the effects of this event, except in the northeastern part of the platform (around the southern part of Liaoning and Jilin and northern part of Hebei) where the Lower and Middle Ordovician succession was believed to be more or less continuous, although some authors (e.g. Liu and Zheng, 1998, figs 3-4; Liu, 2009, fig. 2) suggested a minor gap within the Oepikodus evae Biozone (late Floian). It was mainly from this region that An et al. (1983) established the conodont zonation that has served as the foundation of the Ordovician biostratigraphic framework for North China. More recently Wang et al. (2014) restudied the conodont fauna from the Beianzhang Formation in Tangshan (same section of that of An et al., 1983), northeastern Hebei Province, and established the Histiodella holodentata-Tangshanodus tangshanensis Biozone (Fig. 3) to replace the Tangshanodus tangshanensis and Aurilobodus leptosomatus-Loxodus dissectus biozones of An et al. (1983). Wang et al. (2014) correlated the age of the Beianzhuang Formation with the H. holodentata Biozone (middle Darriwilian, Da2) of the North American conodont succession. Loxodus dissectus An, 1983, another widely distributed species in the Beianzhuang Formation, was also reported co-occurring with $H$. holodentata Ethington and Clark, 1982, in the lower Table Head Formation of western Newfoundland (Stouge, 1984), and in the Mystic Formation of Quebec, Canada (Barnes and Poplawski, 1973). This fauna has been reported from the lower part of the Beianzhuang Formation of the northern and southern regions, and in the lower part of the Zhongliangzi Formation (An and Zheng, 1990, p. 46) and the Zhuozhishan (Wang and Luo, 1984) and Sandaokan (Myrow et al., 2015) formations of the Ordos Basin. Its wide distribution 
indicates that in middle Darriwilian (Da2) time the entire platform was inundated rapidly during a significant regional transgressive event. Although a specimen assignable to the biostratigraphically important conodont Histiodella sinuosa (Graves and Ellison, 1941) was illustrated by An et al. (1983, pl. 25, fig. 3) from the lower part of the Beianzhuang Formation in Tangshan, no locality detail was provided. Its occurrence may suggest that the basal part of the Beianzhuang Formation in the region, which generally had poor yields of conodonts represented by only a few Scolopodus species (Wang et al., 2014a), may extend to the $H$. sinuosa Biozone (Da1, early Darriwilian).

The highest level at the top of the Liangjiashan Formation (or its time equivalent), preserved immediately below the unconformity representing Event 1 in the eastern part of the North China Platform, is characterized by a fauna assigned to the Paraserratognathus obesus-P. paltodiformis Biozone of middle Floian age (Figs. 2-3; Wang et al., 2014b), and thus slightly older than the Jumudontus gananda Biozone. Jumudontus gananda Cooper, 1981, which has an age range from the late Floian to earliest Dapingian (Zhen et al., 2015), was recovered from the top of the Qianzhonglangzi Formation (An and Zheng, 1990, p.42, table 3), immediately underlying the Zhonglangzi Formation of middle Darriwilian age. This contact relationship indicates that - similar to the eastern part (southern and northern regions) of the platform - there is also a hiatus recognizable here with most of the Dapingian to lowermost Darriwilian missing in the western region (Fig. 2). Therefore, these data indicate that the epicontinental sea withdrew completely from the eastern region in the middle Floian and from the western region no later than the earliest Dapingian, as the result of the Huaiyuan Epeirogeny (Event 1). Hence the base of the hiatus represented by the unconformity varies from the upper Cambrian to uppermost Tremadocian in the southern region, from upper Cambrian to basal Dapingian in the western regions, and from the uppermost Tremadocian to lower Darriwilian in the northern region (Fig. 2). 
The younger episode of the Huaiyuan Epeirogeny (Event 2) on the North China Platform initiated a depositional hiatus approximating 122 million years, extending from the latest Ordovician (Ka2) to the latest Mississippian. However, due to extended erosion and karstification during this hiatus, the youngest remaining Ordovician strata in North China varies in age from latest Darriwilian to middle Katian (Fig. 2). This tectonic episode was recently discussed by Chen et al. (2013, fig. 3), who referred to it as the early Katian Uplift Event. As Chen et al. (2013) indicated, the Beiguoshan and Taoqupo formations in the western region contain the youngest Late Ordovician fauna on the North China Platform. Conodonts from these units are readily comparable with the Taoqupognathus tumidusProtoprioniodus insculptus Biozone documented from eastern Australia (Zhen, 2001), dated from associated graptolites as equivalent to the middle Katian (Ka2), and with the Protoprioniodus insculptus Biozone from South China (Zhen et al., in press).

\section{Sedimentary evidence}

The Sanshanzi Formation was interpreted as a forced regressive tract deposited during northward expansion of Huaiyangia from the late Cambrian to middle Floian, mainly based on palaeontological data and the contact relationships discussed in the previous section (An and Zheng, 1990; Zhang and Zhen, 1991; Meng et al., 1997). This apparent regression was also reported near the other palaeo-lands along the west and southwest margins of the platform during the Tremadocian (An et al., 1983, An and Zheng, 1990). Before their dolomitization, the original carbonates were deposited in very shallow environments varying from supratidal, tidal flat to restricted hyper-saline lagoonal settings, evidenced by welldeveloped mudcracks, birds-eye structures, algal mats, cryptalgal stromatolites, evaporites (e.g. gypsum) and solution collapse breccias (Feng and Jin, 1994; Liu et al., 1997; Bai et al., 
2013). Petrological studies undertaken by Feng and Jin (1994) indicated that at least some of well-laminated dolostones formed in supratidal flats (sabkha) under hypersaline conditions.

However, the regression model for the deposition of the Sanshanzi Formation contradicts evidence for a widely recognized eustatic sea-level rise during the Early Ordovician. Furthermore, the accommodation space available for the Lower Ordovician carbonate succession may have reached about $500 \mathrm{~m}$. The preserved thickness of the Sanshanzi Formation varies from $360 \mathrm{~m}$ in areas near the southern margin of the platform to less than $50 \mathrm{~m}$ close to its northern margin. Song (2001) indicated that the original thickness of the Sanshanzi Formation near the southern extreme of its distribution may have been 700 to $850 \mathrm{~m}$, more than twice its currently preserved thickness, but it is difficult to reconcile such a quantity of material being actively eroded from the exposed southern region with continued depositional activities to the immediate north in the retreating epicontinental sea during an uplift event. Therefore, as an alternative model, we postulate that much of the erosion occurred during the late Floian to early Darriwilian when the entire platform was exposed due to regional uplifting (Event 1) coupled with an overall eustatic sea-level fall. The areas towards the south and southwest margins of the platform were exposed first and subjected to longer exposure, resulting in more material at the top of the Lower Ordovician succession (Sanshanzi Formation and time equivalents) being eroded away before the second episode of deposition took place in the late Middle Ordovician (Fig. 2). This new model also raises doubts as to the extent or even existence of Huaiyangia and other palaeolands that were interpreted as existing along the margins of the platform during the Early Ordovician (Zhang and Zhen, 1991; Chen et al., 1995). Without the support of the facies contact relationship against the palaeo-lands, the absence of Lower Ordovician deposits in those areas occupied by the supposed palaeo-lands is more likely the result of subsequent erosion during Event 1 or/and Event 2 of the Huaiyuan Epeirogeny. For instance, the 
Sandaokan Formation of middle Darriwilian age (Myrow et al., 2015), in the Zhuozishan area (near Shizuishan) on the western margin of the platform, disconformably overlies upper Cambrian rocks. Occurrence of reworked Tremadocian conodonts (e.g. Chosonodina herfurthi; see Wang and Luo, 1984) in the Sandaokan Formation supports the interpretation that the Lower Ordovician in the area was completely eroded away during Event 1 of the Huaiyuan Epeirogeny.

The upper Middle-Upper Ordovician succession was deposited in a similar shallowwater setting, with widely distributed dolostone flats and salt-bearing lagoons (including gypsum, halite, anhydrite and other evaporites). Detailed lithofacies analysis of the younger Ordovician successions on the North China Platform demonstrated that the dolostones were mainly distributed at the periphery of the carbonate deposition system in a supratidal setting, and that gypsum, halite and other evaporites formed in the depressions, suggesting that much of the epicontinental sea was very shallow with hypersaline conditions prevailing in many parts of the carbonate platform (Feng et al., 2014).

Basal breccia, conglomeratic sandstone and conglomerate widely distributed at the base of the upper Middle Ordovician Beianzhuang Formation and its correlatives demonstrate that erosion and sub-aerial exposure of the Lower Ordovician took place before the transgression event in the late Middle Ordovician (Fig. 2). Clasts of the conglomerates were mainly derived from the underlying dolostone units (Ma et al., 1998). Detailed regional mapping and sedimentary data (Song, 2001) from Shandong and adjacent areas (southern region) indicated that the erosion was stronger southward, with well-rounded clasts forming the conglomerates located near the southern extreme suggesting extensive transportation. A similar type of conglomerate was also reported from the base of the Sandaokan Formation and other units in the area towards the southwest and west margins of the platform (An and Zheng, 1990; Liu et al., 1997). Typical erosion surfaces, dissolution features (dissolved 
pores and cavities) and small-scale palaeokarstification were recorded on the top of the underlying Lower Ordovician (e.g. Sanshanzi Formation or Liangjiashan Formation) in southern (Liu et al., 1997; Ma et al., 1998; Song, 2001; Zhang et al., 2005) and western (Bai et al., 2013) regions. These sedimentary features provide direct evidence of the significant sub-aerial erosion of the Lower Ordovician succession on the North China Platform before deposition of the upper Middle and Upper Ordovician sequence.

Palaeokarstification, typically forming karst platforms, slopes, and basins, was well developed on the top surface of the Ordovician (Miao and Bai, 2011). Through intensive meteoric leaching, weathering, erosion, and karstification over an extended time interval from the latest Ordovician to Mississippian (Event 2), parts of the Upper Ordovician were eroded away to form a landscape with valleys of significant depth among low hills, before flooding of the platform during the Pennsylvanian transgression. Some of the karst valleys are at least 400-500 m deep, suggesting that the minimum uplift during Event 2 would have been of this magnitude. Bauxite deposits (known as the G layer bauxites) and iron ore (referred as to Shanxi Type Iron Ore, mainly limonite and hematite) are widely distributed at the base of the upper Carboniferous succession that directly overlies the Ordovician carbonates on the North China Platform. These mineral deposits have been interpreted as derived either from weathering and erosion of the underlying Ordovician limestone under moist and hot climatic conditions (Liu, 1988), or from tephra deposited on the Ordovician erosional surface (Liu et al., 2014).

\section{Sea-level changes}

For comparative purposes, the Ordovician sea-level curve derived from Laurentia (Ross and Ross, 1995) is shown on Figure 2, not only because it relies on more detailed palaeontological and sedimentary data to calibrate the curve, but also because Laurentia (and 
Siberia) shared palaeogeographical and depositional settings similar to those of the North

China Platform during the Ordovician. Although the Lower Ordovician sequence of the North China Platform was deposited during the overall eustatic sea-level rise in the Early Ordovician, the succeeding uplift event (Event 1) can only be roughly compared with the Dapingian and early Darriwilian overall eustatic sea-level fall, as it took place slightly earlier, at about the time of the maximum eustatic sea-level rise (the evae Biozone) recorded elsewhere (Munnecke et al., 2010, fig. 1).

Palaeontological and other data indicate that the younger Ordovician succession on the North China Platform was deposited during an apparent transgression commencing in the middle Darriwilian. The deeper water facies of the platform margin (Pingliang and Longmendong formations) advanced over the platform succession on the western margin of the platform, reaching a maximum extent in the latest Darriwilian to early Sandbian, which corresponds to the eustatic sea-level rise recognized globally (Fig. 2). More specifically, this flooding event generally coincides with the overall transgression of the latest Middle Ordovician recognized from Laurentia (Ross and Ross, 1995), Siberia (Kanygin et al., 2010), and other palaeo-continents (Munnecke et al., 2010, fig. 1), although it apparently started slightly earlier (middle Darriwilian, Da2) on the North China Platform (Fig. 2). Therefore tectonic events, rather than eustatic sea-level changes, were the major factor controlling deposition during the late Middle to Late Ordovician on the North China Platform. Studies of the lithofacies analysis and sequence stratigraphy (Meng et al, 1997; Liu and Zheng, 1998; Ma et al., 1998) recognized a stacking pattern of shallowing-upward cycles of various scales in the both successions (Lower Ordovician, and upper Middle to Upper Ordovician) on the North China Platform. Liu and Zheng (1998) indicated that the development of cyclicity in the succession was predominantly controlled by eustatic fluctuations, and the tectonic movements mainly affected the larger scale cycles. 
Rippendan et al. (1993, fig. 5) used Carbon isotope analyses to recognize several significant hiatuses in Cambrian-Ordovician boundary beds (lower Tremadocian and uppermost Cambrian) at Xiaoyangqiao near Dayangcha of Jinlin Province, and related them to either eustatic sea-level falls or regional regressive events. Dayangcha is located near the northern margin of the North China Platform, and the carbonate-dominated Lower

Ordovician successions in the area are characterized by the alternation of thinly-bedded calcareous mudstone or siltstone, biomicrudite and micrite (Chen, 1986). Occurrence of sponge spicule-bearing micrite and predominance of an alternating succession of carbonatemarl-mudstone indicate that these sediments were deposited in relatively deep water outershelf to marginal platform environments. This study also demonstrated that interruptions to sedimentation caused by eustatic sea-level falls and regional regressive events were not restricted to the shallow water interior of the North China Platform, but apparently extended to the deeper part of the platform, such as in the outer-shelf settings, or even into the slope environment (Chen, 1986; Liu and Zheng, 1998).

\section{Mechanism and possible causes}

Evidence presented above shows that the timing of the first event of the Huaiyuan Epeirogeny extended from the middle Floian to early Darriwilian when the entire platform was uplifted, and was followed by the second event, which uplifted the platform and terminated the sedimentation for a much more extended period from the latest Ordovician (late Katian) to the latest Mississppian (Zhang and Zhen, 1991; Yin and Nie, 1996). These two tectonic events ultimately controlled Ordovician deposition on the North China Platform, and constrain two distinct sedimentary packages separated by two unconformities, one of Early Ordovician age, and the other of late Middle to Late Ordovician age. 
The two events of the Huaiyuan Epeirogeny have been interpreted as the results of uplifting of the cratonic basement (Zhang and Zhen, 1991; Song, 2001; Bai et al., 2013), related to major tectonism along the south and north plate margins. In particular, Event 1 might be closely related to the transformation of its southern plate margin from passive to active (Bai et al., 2013), and Event 2 may be a consequence of a series of collisions of accretion complexes and island arcs along the subduction zones bordering its current north and south margins (de Jong et al., 2006; Kusky et al., 2007). Examples include the Ordovician oceanic subduction of the Erlanping arc along its current southern margin of the North China Craton (Faure et al., 2008, fig. 7) and the accretion of the Hunia terrane to its current southern margin during the Katian (von Raumer and Stampfli, 2008, fig. 7E), and the successive accretions of the Ondor Sum accretionary complex, Ulan arc and Bainaimiao magmatic arc to its current northern margin during the Ordovician-Silurian (de Jong et al., 2006, figs 2, 4).

Fossil age evidence from the top surface of the Ordovician led Chen et al. (2013) to argue that the younger episode of the Huaiyuan Epeirogeny might have commenced as early as late Sandbian, and hence they related this event to the Kwangsian Orogeny recognized in South China. However, we interpret the evidence to show that the two events of the Huaiyuan Epeirogeny were closely related, with Event 1 forming the prelude to Event 2, and that they were significantly different in both nature and magnitude from either the Kwangsian Orogeny or the Caledonian Orogeny (both of which have often been suggested as analogues of the later event of the Huaiyuan Epeirogeny). Although tectonic events played a major role in the sedimentation of the Ordovician rocks on the North China Platform, significant contributions of eustatic sea-level changes cannot be ruled out, particularly in the formation of smaller scale fluctuations (fourth or fifth order cycles; Liu and Zheng, 1998). The dramatic eustatic sea-level fall of up to $160 \mathrm{~m}$ at the end of the 
Ordovician, due to effects of the Hirnantian glaciation, would no doubt have driven the sea completely off the platform. Liu et al. (1997) also argued that although what is now recognized as Event 2 of the Huaiyuan Epeirogeny was the result of a vigorous uplift, Event 1 defined herein was caused by eustatic sea-level fall exceeding the rate of basement subsidence. Based on the analysis presented above, it is more likely that the Lower Ordovician deposits accumulated as rapid sediment infill on the platform exceeded the rate of basement subsidence and overall sea-level rise in the Early Ordovician, followed by significant uplift (and/or eustatic sea-level fall) from the middle Floian to early Darriwilian that terminated sedimentation. This proposed scenario, supported by available palaeontological and sedimentary data, better explains development of the accommodation space required for the deposition of the relatively thick Lower Ordovician carbonate succession found on the North China Platform.

\section{Conclusions}

The original definition of the Huaiyuan Movement is expanded (and renamed the Huaiyuan Epeirogeny) to include the two tectonic episodes represented by the unconformity between the Lower and Middle Ordovician (Event 1), and the unconformity between uppermost Middle-Upper (Ka2) Ordovician and the overlying upper Carboniferous (Event 2). The combined effects of these events reflect significant differences in timing, nature and magnitude compared with either the Kwangsian or Caledonian orogenies.

Conodont faunas from the Liangjiashan and Beianzhuang formations immediately below and above the older unconformity indicate that the platform-wide hiatus ranges from the middle Floian (Early Ordovician) to early Darriwilian (Middle Ordovician), a depositional gap significantly longer and more widely distributed than previously recognized. 
Palaeontological and sedimentological evidence supports the view that combined with major eustatic sea-level changes (e.g. in comparison with the sea-level curve generated from Laurentian data, see fig. 2), the Huaiyuan Epeirogeny represents regional tectonic movements that shaped and controlled the regional stratigraphy and sedimentation of the North China Platform during the Ordovician. Although relative intensities of tectonism compared with sea-level changes cannot be easily quantified and distinguished, the Huaiyuan Epeirogeny can be presumed to have played a decisive role when the regional facies architecture and depositional patterns contradict those of contemporaneous global eustatic patterns. More specifically, the Lower Ordovician deposition took place with rapid sediment infill on the platform exceeding the rate of basement subsidence and overall sealevel rise in the Tremadocian. Event 1 of the Huaiyuan Epeirogeny represents a significant uplift partly in concert with a major eustatic sea-level fall from middle Floian to early

Darriwilian times. The extent of the unconformity resulting from this depositional hiatus was exacerbated by considerable erosion superimposed on Lower Ordovician deposits, particularly in the areas close to south and southwest margins of the platform where the disconformity cuts down into Tremadocian or even upper Cambrian rocks. The upper Middle to Upper Ordovician succession was deposited during a second interval of basement subsidence coupled with a major eustatic sea-level rise before Event 2, when the entire platform was uplifted again, coinciding with one of the largest eustatic sea-level falls in Phanerozoic history, and subsequently underwent an extended period of erosion.

\section{ACKNOWLEDGMENTS}

The senior author acknowledges the support of his visit to China from April to May of 2015 by the Chinese Academy of Sciences (SAFEA Program), National Science Foundation of China (No. 41290260 to Zhang) and Ministry of Science and Technology of China 
(No.2011ZX05008001-10 to Zhang), when the manuscript was finalized. Song Y.-Y. is thanked for helping with the final drafting of figure 1. An anonymous reviewer is acknowledged for the careful and constructive review of the manuscript. This is a contribution to IGCP Project 591: The Early to Middle Palaeozoic Revolution. YYZ and IGP publish with the permission of the Director, Geological Survey of New South Wales.

\section{References}

An, T.X., Zheng, S.C., 1990. The conodonts of the marginal areas around the Ordos Basin, north China. Science Press, Beijing. 199 pp. (in Chinese with English abstract).

An, T.X., Zhang, F., Xiang, W.D., Zhang, Y.Q., Xu, W.H., Zhang, H.J., Jiang, D.B., Yang, C.S., Lin, L.D., Cui, Z.T., Yang, X.C., 1983. The Conodonts of North China and the Adjacent Regions. Science Press, Beijing. 223 pp. (in Chinese with English abstract).

Bai, Y.L., Ma, Y.H., Huang, Y., Liao, J.B., Liu, X.G., 2013. Properties of Continental Margin and its Hydrocarbon Exploration Significance in Cambrian in the Southern Ordos Kratogen of North China. Acta Geologica Sinica (English Edition) 87, (3), 777-803.

Barnes, C.R., Poplawski, M.L.S., 1973. Lower and Middle Ordovician conodonts from the Mystic Formation, Québec, Canada. Journal of Paleontology 47, 760-790.

Cao, J.Z., Feng, Q., Zhao, W., Zhou, S.C., Wang, Q.Y., Liu, Z., Lu, Y.J., Li, Y.L., 2011. Sequence stratigraphy of Ordovician strata in the south part of Ordos area. Acta Sedimentologica Sinica 29 (2), 286-292. (in Chinese with English abstract)

Chen, J. (ed.), 1986. Aspects of Cambrian-Ordovician Boundary in Dayangcha, China. China Prospect Publishing House, Beijing. 406 pp.

Chen, X., Rong, J.Y., Wang, X.F., Wang, Z.H., Zhang, Y.D., Zhan, R.B., 1995. Correlation of the Ordovician rocks of China: Charts and explanatory notes. International Union of Geological Sciences, Publication 31, 1-104. 
Chen X., Bergström, S.M., Zhang, Y.D., Wang, Z.H., 2013. A regional tectonic event of Katian (Late Ordovician) age across three major blocks of China. Chinese Science Bulletin 58 (34), 4292-4299.

Cho, D.L., Lee, S.R., Koh, H.J., Park, J.P., Armstrong, R., Choi, D.K., 2014. Late Ordovician volcanism in Korea constrains the timing for breakup of Sino-Korean Craton from Gondwana. Journal of Asian Earth Sciences 96, 279-286.

Cooper, B.J., 1981. Early Ordovician conodonts from the Horn Valley Siltstone, central Australia. Palaeontology 24, 147-183.

de Jong, K., Xiao, W.J., Windley, B.F., Masago, H., Lo, C.-H., 2006. Ordovician 40Ar/39Ar phengite ages from the blueschist-facies Ondor Sum subduction-accretion complex (Inner Mongolia) and implications for the early Palaeozoic history of continental blocks in China and adjacent areas. American Journal of Science 306, 799-845.

Ethington, R.L., Clark, D.L., 1982. Lower and Middle Ordovician conodonts from the Ibex area, western Millard County, Utah. Brigham Young University, Geological Studies 28 (2), 1-160.

Faure, M., Lin, W., Monié, P., Meffre, S., 2008. Palaeozoic collision between the North and South China Blocks, Triassic intracontinental tectonics, and the problem of the ultrahighpressure metamorphism. Comptes Rendus Géosciences, Académie des Sciences / Elsevier Masson 340, 139-150. Feng, Z.Z., Jin, Z.K., 1994. Types and origin of dolostones in the Lower Palaeozoic of the North China Platform. Sedimentary Geology $93(3-4), 279-290$.

Feng, Z.Z., Zheng, X.J., Bao, Z.D., Jin, Z.K., Wu, S.H., He, Y.B., Peng, Y.M., Yang, Y.Q., Zhang, J.Q., Zhang, Y.S., 2014. Quantitative lithofacies palaeogeography. Journal of Palaeogeography 3 (1), 1-34. 
Graves, R.W., Ellison, S., 1941. Ordovician conodonts of the Marathon Basin, Texas. University of Missouri, School of Mines and Metallurgy, Bulletin of the Technical Series $14,1-26$.

Kanygin, A., Dronov, A., Timokhin, A., Gonta, T., 2010. Depositional sequences and palaeoceanographic change in the Ordovician of the Siberian craton. Palaeogeography, Palaeoclimatology, Palaeoecology 296, 285-296.

Kusky, T.M., Windley, B.F., Zhai, M.G., 2007. Tectonic evolution of the North China Block: from orogen to craton to orogen. Geological Society, London, Special Publication 280, $1-34$.

Li, S.G. (Lee, J.S.), 1939. The geology of China. Thomas Murby and Co., Woodbridge Press, London. 528 pp.

Liu, B., Wang, Y.H., Qian, X.L., 1997. Two Ordovician unconformities in North China: Their origins and relationships to regional carbonate-reservoir characteristics. Carbonates and Evaporites 12 (2), 177-184.

Liu, C.M., 1988. Geological features and genesis of Carboniferous bauxite in China. Acta Sedimentologica Sinica 6 (3), 1-10. (in Chinese with English abstract).

Liu, J., Zhao, Y., Liu, A.K., Zhang, S.H., Yang, Z.Y., Zhuo, S.G., 2014. Origin of Late Palaeozoic bauxites in the North China Craton: Constraints from zircon $\mathrm{U}-\mathrm{Pb}$ geochronology and in situ Hf isotopes. Journal of the Geological Society 171 (5), 695707.

Liu, J.B., 2009. Marine sedimentary response to the Great Ordovician Biodiversification Event: Examples from North China and South China. Paleontological Research 13 (1), $9-21$. 
Liu, J.B., An, T.X., Zheng, Z.C., 1996. Sedimentary evolution of the Ordovician basin in central Ningxia, North China. Journal of Geosciences, Osaka City University 39 (5), 83 110.

Liu, J.B., Zheng, Z.C., 1998. Stacking patterns and correlation of meter-scale shallowingupward cycles in the Lower Ordovician carbonates in Pingquan and Qinglongshan, North China. Journal of Geological Society of Japan 104 (5), 327-345.

Ma, X.P., Han, Z.Z., Wang, Y.H., 1998. The Tremadocian-early Arenigian( Early Ordovician) sequence stratigraphy and lithofacies paleogeography of North China. Scientia Geologica Sinica 33 (2), 166-179. (in Chinese with English abstract).

Metcalfe, I., 1996. Gondwanaland dispersion, Asian accretion and evolution of Eastern Tethys. Australian Journal of Earth Sciences 43, 605-623.

Metcalfe, I., 1998. Palaeozoic and Mesozoic geological evolution of the SE Asian region: multidisciplinary constraints and implications for biogeography. In R. Hall amd J.D. Holloway (eds), Biogeography and Geological evolution of SE Asia. Backhuys Publishers, Amsterdam, 25-41.

Metcalfe, I., 2006. Palaeozoic and Mesozoic tectonic evolution and palaeogeography of East Asian crustal fragments: The Korean Peninsula in context. Gondwana Research 9, 2446.

Meng, X.H., Ge, M., Tucker, M.E., 1997. Sequence stratigraphy, sea-level changes and depositional systems in the Cambro-Ordovician of the North China carbonate platform. Sedimentary Geology 114 (1-4), 189-222.

Miao, X.X., Bai, H.B., 2011. Water-resisting characteristics and distribution rule of carbonate strata in the top of Ordovician in North China. Journal of China Coal Society 36 (2), 185-193. (in Chinese with English abstract). 
Munnecke, A., Calner, M., Harper, D.A.T., Servais, T., 2010. Ordovician and Silurian seawater chemistry, sea level, and climate: A synopsis. Palaeogeography, Palaeoclimatology, Palaeoecology 296, 389-414.

Myrow, P.M., Chen, J.T., Snyder, Z.C., Leslie, S., Fike, A.A., Fanning, C.M., Yuan, J.L., Tang, P., 2015. Depositional history, tectonics, and provenance of the CambrianOrdovician boundary interval in the western margin of the North China block. Geological Society of America Bulletin. (Published online 2015, doi:10.1130/B31228.1).

Von Raumer, J.F., Stampfli, G.M., 2008. The birth of the Rheic Ocean — Early Palaeozoic subsidence patterns and subsequent tectonic plate scenarios. Tectonophysics 461(1-4.1), $9-20$.

Ripperdan, R.L., Magaritz, M., Kirschvink, J.L., 1993. Carbon isotope and magnetic polarity evidence for non-depositional events within the Cambrian-Ordovician Boundary section near Dayangcha, Jilin Province, China. Geological Magazine 130 (4), 443-452.

Ross, C.A., Ross, J.R.P., 1995. North American depositional sequences and correlations. In: Cooper, J.D., Droser, M.L., Finney, S.C. (Eds.), Ordovician Odyssey: Proceedings of 7th International Symposium on the Ordovician System, Pacific Section. SEPM, California, Fullerton, pp. 309-313.Song, D.N., 2001. Re-recognization of Huaiyuan Movement. Geology of Shandong 2001, 1, 19-23, 51. (in Chinese with English abstract).

Stouge, S., 1984. Conodonts of the Middle Ordovician Table Head Formation, western Newfoundland. Fossils and Strata 16, 1-145.

Wang, Y., Zhou, L., Zhao, L., Ji, M., Gao, H., 2010. Palaeozoic uplands and unconformity in the North China Block: Constraints from zircon LA-ICP-MS dating and geochemical analysis of Bauxite. Terra Nova 22 (4), 264-273. 
Wang, Z.H., Luo, K.Q., 1984. Late Cambrian and Ordovician conodonts from the marginal areas of the Ordos Platform, China. Bulletin, Nanjing Institute of Geology and Palaeontology, Academia Sinica 8, 237-304. (in Chinese with English abstract).

Wang, Z.H., Bergström, S.M., Zhen, Y.Y., Zhang, Y.D., 2013a. New discovery of conodonts from the Upper Ordovician Pingliang Formation of Pingliang, Gansu, China and its significance. Acta Micropalaeontologica Sinica 30 (2), 123-131. (in Chinese with English abstract).

Wang, Z.H., Bergström, S.M., Zhen, Y.Y., Zhang, Y.D., Wu, R.C., Chen, Q., 2013b. Ordovician conodonts from Dashimen, Wuhai in Inner Monglolia and the significance of the discovery of the Histiodella fauna. Acta Micropalaeontologica Sinica 30 (4), 323343. (in Chinese with English abstract).

Wang, Z.H., Bergström, S.M., Zhen Y.Y., Chen, X., Zhang, Y.D., 2013c. On the integration of Ordovician conodont and graptolite biostratigraphy: new examples from Gansu and Inner Mongolia in China. Alcheringa 37, 510-528.

Wang, Z.H., Bergström, S.M., Zhen, Y.Y., Zhang, Y.D., Wu, R.C., 2014a. A revision of the Darriwilian biostratigraphic conodont zonation in Tangshan, Hebei Province based on new conodont collections. Acta Palaeontologica Sinica 53, 1-15. (in Chinese with English abstract).

Wang, Z.H., Bergström, S.M., Zhen, Y.Y., Zhang, Y.D., Wu, R.C., 2014b. New conodont data from the Lower Ordovician of Tangshan, Hebei Province, North China. Acta Micropalaeontologica Sinica 31 (1), 1-14. (in Chinese with English abstract).

Wu, X.Z., Min, Z.M., 2015. Features and geotectonic evolution of the Alxa Terrane at North Qilian Mountains in China. Geophysical Research Abstracts Vol. 17, EGU2015-4270. 
Xiao, W.J., Kröner, A., Windley, B., 2009. Geodynamic evolution of Central Asia in the Paleozoic and Mesozoic. International Journal of Earth Sciences (Geologische Rundschasu) 98, 1185-1188.

Yang, J.H., O’Reilly, S., Walker, R.J., Griffin, W., Wu, F.Y., Zhang, M., Pearson, N., 2010. Diachronous decratonization of the Sino-Korean craton: Geochemistry of mantle xenoliths from North Korea. Geology 38 (9), 799-802.

Yang, Y.T., Li, W., Ma, L., 2005. Tectonic and stratigraphic controls of hydrocarbon systems in the Ordos basin: A multicycle cratonic basin in central China. AAPG Bulletin 89 (2), $255-269$.

Yin, A., Nie, S., 1996. A Phanerozoic palinspastic reconstruction of China and its neighbouring regions. In A. Yin and T.M. Harrison (eds), The tectonic evolution of Asia. Cambridge University Press, Cambridge, 442-485.

Yuan, W., Yang, Z.Y., 2015. The Alashan Terrane did not amalgamate with North China block by the Late Permian: Evidence from Carboniferous and Permian paleomagnetic results. Journal of Asian Earth Sciences. (Published online 2014, doi:10.1016/j.jseaes.2014.02.010).

Zhai, M., Santosh, M., 2013. Metallogeny of the North China Craton: Link with secular changes in the evolving Earth. Gondwana Research 16 (2), 321-341.

Zhang, J., Zhang, Y.P., Xiao, W.X., Wang, Y.N., Zhang, B.H., 2014. Linking the Alxa Terrane to the eastern Gondwana during the Early Paleozoic: Constraints from detrital zircon $\mathrm{U}-\mathrm{Pb}$ ages and Cambrian sedimentary records. Gondwana Research . (Published online 2014, http://dx.doi.org/10.1016/j.gr.2014.09.012).

Zhang, S.X., Zhen, Y.Y., 1991. China. In M. Moullade and A.E.M. Nairn (eds), The Phanerozoic geology of the world I, the Palaeozoic A. Elsevier Science Publishers, Amsterdam, 219-274. 
Zhang, X.L., Wang, Y.H., Pang, R.S., 1991. Petrographic features and sedimentary environments of the Middle-Upper Ordovician at Shetai Town of Urad Front Banner, Inner Mongolia. Acta Geologica Sinica, 4 (4), 401-416.

Zhang, Y.F., Li, Z., Wang, Q.C., Kong, Q.Y., 2005. Diagenesis and its role on the reservoir of Ordovician Carbonate rocks in the west Shandong Rise. Chinese Journal of Geology 40 (2), 207-219. (in Chinese with English abstract)

Zhang, Z.M., Liou, J.G., Coleman, R.G., 1984. An outline of the plate tectonics of China. Geological Society of America Bulletin 95 (3), 295-312.

Zhao, G.C., Zhai, M.G., 2013. Lithotectonic elements of Precambrian basement in the North China Craton: Review and tectonic implications. Gondwana Research 23, 1207-1240.

Zheng, Y.F., Xiao, W.J., Zhao, G.C., 2013. Introduction to tectonics of China. Gondwana Research 23, 1189-1206.

Zhen, Y.Y., 2001. Distribution of the Late Ordovician conodont genus Taoqupognathus in eastern Australia and China. Acta Palaeontologica Sinica 40 (3), 351-361.

Zhen, Y.Y., Percival, I.G., Zhang, Y.D., 2015. Floian (Early Ordovician) conodont-based biostratigraphy and biogeography of the Australasian Superprovince. Palaeoworld 24, 100-109.

Zhen, Y.Y., Percival, I.G., Molloy, P.D. (in review). Late Ordovician conodonts and brachiopods from limestones within the Wairuna Formation, Broken River Province, north Queensland. Proceedings of the Linnean Society of New South Wales.

\section{Captions}

Figure 1. Map of North China plate showing major tectonic stratigraphic framework of the Ordovician (modified from Zheng et al., 2013). 
Figure 2. Two events of the Huaiyuan Epeirogeny and the spatial and temporal distribution

of the two unconformities that separate the Ordovician sequences on the North China

Platform, correlated with conodont zonation and eustatic sea level changes (Laurentia, after Ross and Ross, 1995).

Figure 3. A-O, Representative species of the Histiodella holodentata-Tangshanodus tangshanensis Biozone (middle Darriwilian) from the Beianzhuang Formation (A-E, I-J, L, $\mathrm{N}-\mathrm{O}$ ) and Zhuozishan Formation (F-H, K, M), overlying the disconformity that marks Event 1 of the Huaiyuan Epeirogeny on the North China Platform. A, Loxodus dissectus An, 1983; P element, C33-10, inner lateral view. B, Rhipidognathus maggolensis (Lee, 1976); Sc element, C31-1, posterior view. C-E, Rhipidognathus laiwuensis Zhang in An et al., 1983; C, Sb element, C31-7, posterior view; D, Sc element, C35-4, posterior view; E, Sa element, C31-1, posterior view. F, Paroistodus horridus (Barnes and Poplawski, 1973); S element, bed 37, outer lateral view. G-L, Tangshanodus tangshanensis An in An et al., 1983; G, Sc element, bed 36, outer-lateral view; H, Pa element, bed 29, inner lateral view; I, Pa element, C29-2, outer lateral view; J, Pb element, C34-2, inner lateral view; K, Sa element, bed 29, lateral view; L, Sa element, C29-2, lateral view. M-O, Histiodella holodentata Ethington and Clark, 1982. Pa element; M, bed 36, outer-lateral view; N, C36-3, inner lateral view; O, C31-4, outer lateral view.

P-Z, Representative species of the early-middle Floian conodonts (Serratognathus bilobatus, S. extensus and Paraserratognathus obesus-P. paltodiformis biozones) from the Liangjiashan Formation, underlying the disconformity that marks Event 1 of the Huaiyuan Epeirogeny on the North China Platform. P-S, Paraserratognathus obesus Yang in An et al., 1983; S element; P, C24-3, posterior view; Q-S (C24-2, C23-4, C23-9), lateral views. T-U, 
614 Serratognathus extensus Yang in An et al., 1983; T, Sb element, C24-1, anterior view; U, Sa 615 element, C24-1, upper view. V-W, Serratognathus bilobatus Lee, 1970; V, Sb element, 616 C23-1, anterior view; W, Sa element, C19-4, posterior view. X-Z, Bergstroemognathus 617 extensus (Graves and Ellison, 1941); X, Sa element, C19-4, posterior view; Y, Pb element, $618 \mathrm{C} 23-1$, inner lateral view; Z, Pb element, C24-2, inner lateral view. Scale bars $0.1 \mathrm{~mm}$. 


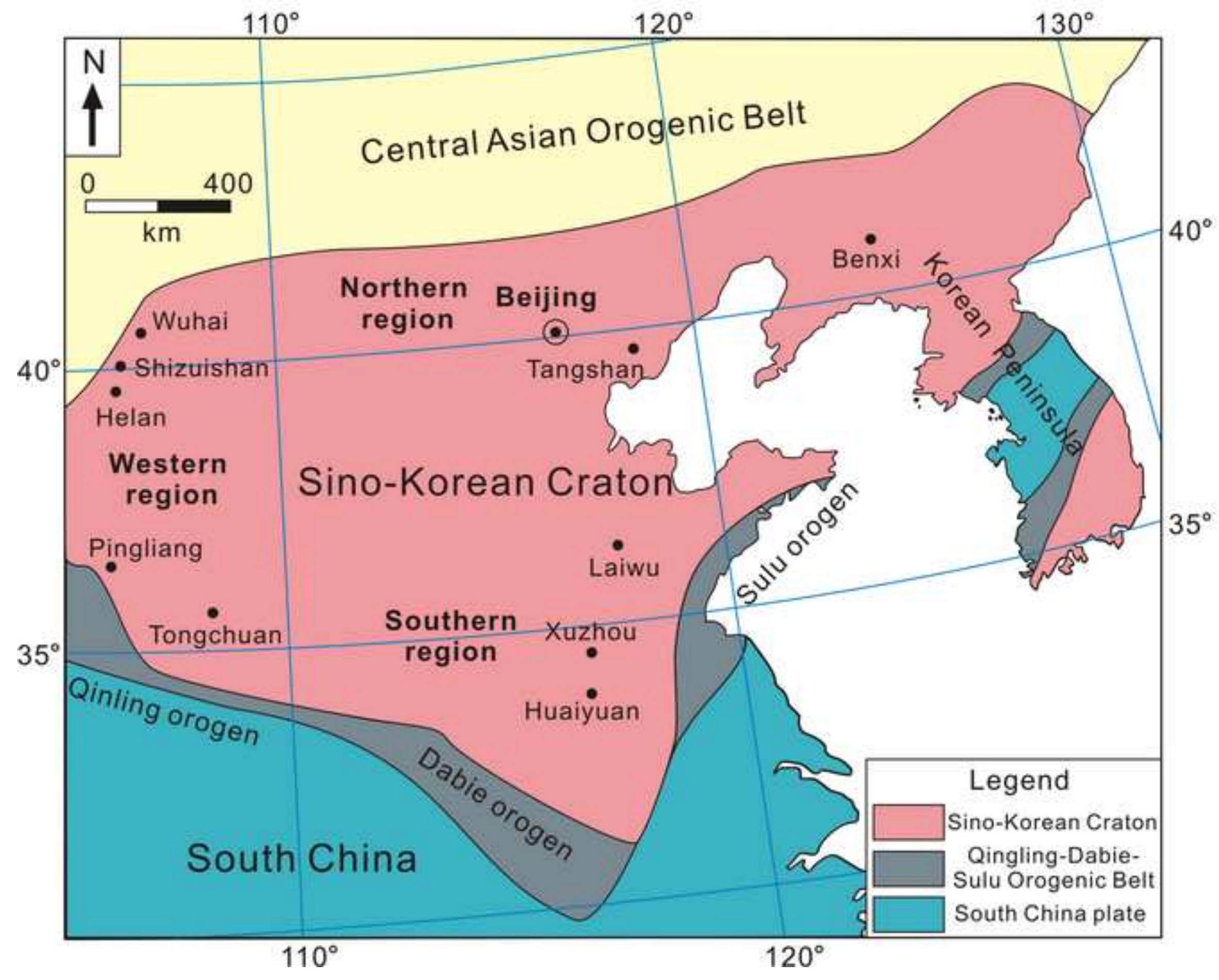




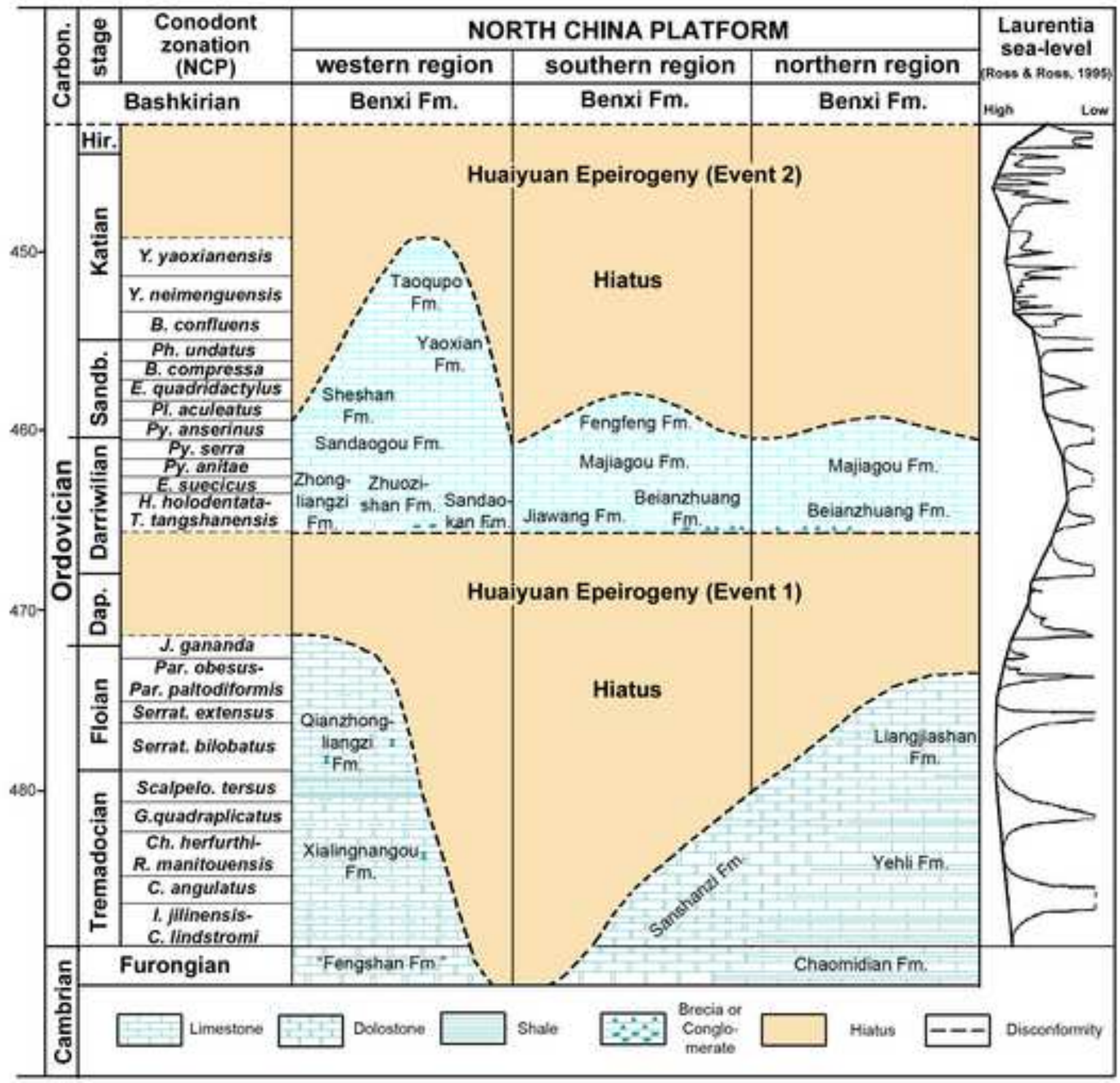




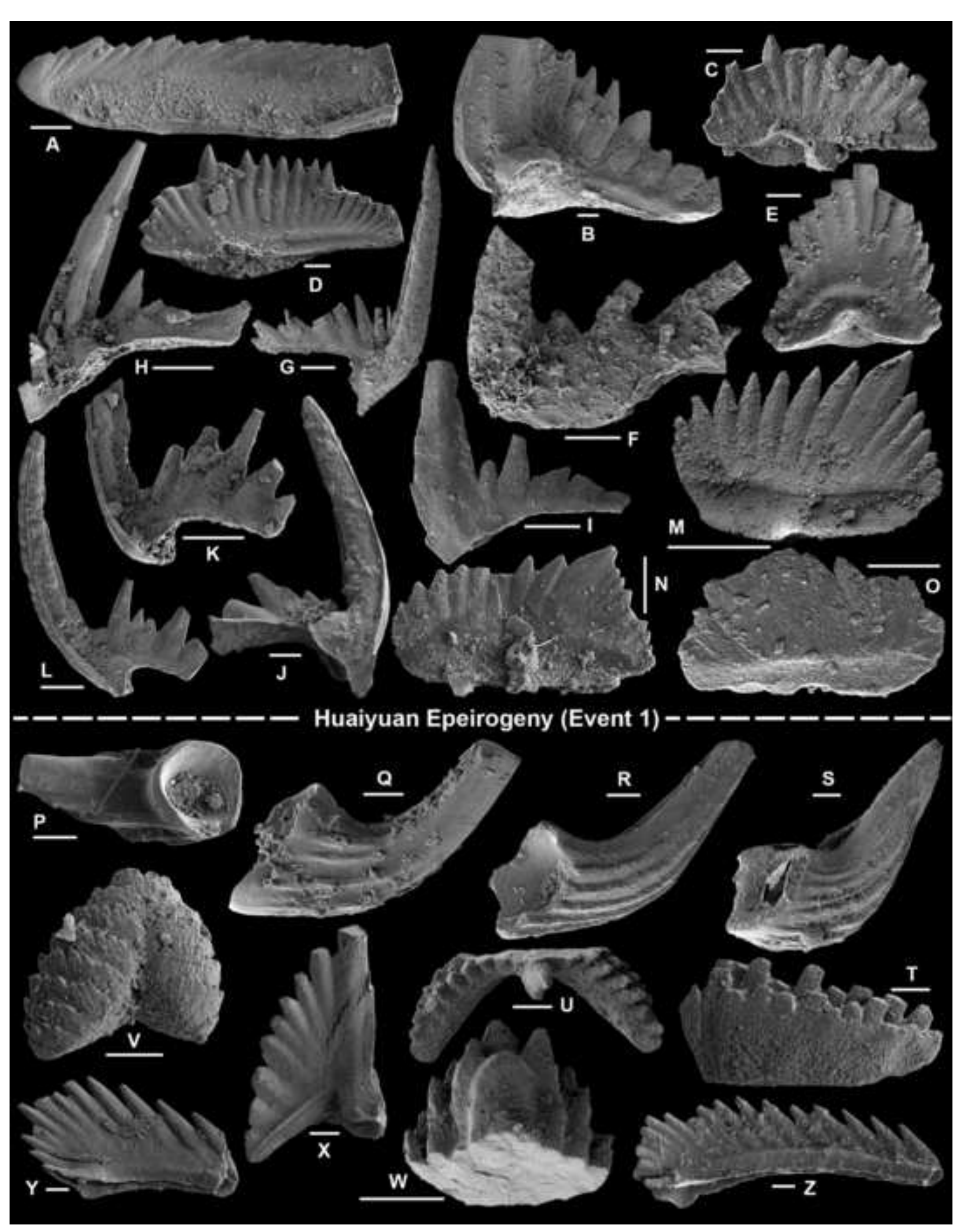

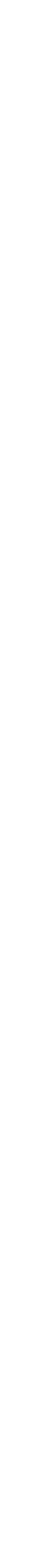

3

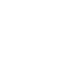

